belief that my work does not throw any light upon the causes of variation. There are however many zoologists who believe that it has such a bearing, and indeed it seems only natural that writers (such as Dr. Romanes himself) who retain the Lamarckian conception of the direct influence of surroundings in causing the variations of the higher animals, should believe (as I think wrongly) that they see evidence for the soundness of their views in the results of experiments in which the colours of insects have been completely modified in a single generation by the action of environment.

Oxford, July 15.

\section{The Thunder-Axe.}

ThOSE who are interested in the study of anthropology need no reminder as to the European belief in a connection between ancient stone weapons and thunder. It would be mere waste of time if I quoted instances of this connection ; but it may not be devoid of interest to some of your readers if I bring to their notice a modern account of the thunder-weapon, as described to-day by a New Zealander. The account may also be of service to those studying another branch of anthropology-that concerning the influence and value of ancient and modern creeds warring in the minds of semi-civilized peoples. I shall make no comment of my own, but proceed to give a translation of a tale printed (in Maori only) in the pages of the native newspaper, the Korimako. The few words in it which were not understood by those acquainted with the ordinary Maori speech, I referred to old men well versed in the dialect of that part of New Zealand.

$$
\text { "The finding of } T e \text { Awhiorangi. }
$$

"The tribes of this island have hitherto only heard of Te Awhiorangi, but have not seen it. We, Ngarauru--that is, the people descended from Rangitaupea, our ancestor who hid the axe-bave never seen it until now . . One of our settlements, called Okutuku, is near Waitotara. Twenty natives from this settlement proceeded in a party for the purpose of gathering the edible fungus (Hâkekâkeka) for the purpose of sale. With the party went a young woman whose name was Tomairangi (Dew of Heaven), the wife of Te Potonga Kaiawha. This gir was a perfect stranger in the district: she did not know where the sacred (tapu) places were; she belonging to the Ngaitahu (a South Island tribe), but her father was of us, the Ngarauru. The girl wandered away by herself, looking here and there, searching for trees on which the fungus grew. She saw a tree on which there was fungus, and laid her hand on it, but suddenly there came the flash of the Axe. Following with her eyes the direction of the flash, she saw the Axe close against the foot of a Pukater tree; a cry of terror broke from her, and she fled screaming. At the same time the thunder roared, the lightning flashed, and blinding hail burst forth in sudden storm, increasing her terror almost to madness. Her husband heard her cries as she flew along: but an old man, called Te Rangi Whakairione, directly he heard her shrieks, understood the reason of the outcry, so he began to chant an incantation, and the fury of the storm abated. When the party had assembled together in the open land, the old priest asked which of them had been to Tieke; whereupon the girl asked 'Where is Tieke?' The old man answered that it was beyond the turn at Waione. Tomairangi replied, 'I have been there, but I did not know it was a sacred place: I saw something that looked like a spirit, and I am full of great fear.' Then all the party went to ascertain what it was, and then they found that it was indeed the lost sacred Axe, Te Awhiorangi. After Te Rangi Whaliairione had chanted another incantation over it, they all took hold of the Axe, and wailed over it. When the crying had ceased, they brought the Axe back to the settlement. All the tribe knew that the Axe was somewhere in that vicinity, for our ancestor Rangitaupea had passed the secret on to his children in the words, "Te Awhiorangi is at Tieke on the plain close above the Cave of the Dead.' Until now that place has been unvisited, being entirely sacred till this day, the roth of December, 1887 . Then gathered all Ngarauru and some of the Whanganui and Ngatiapa tribes, in number 300 persons, and at dawn the next day the sacred thing was hung up on a tree that all might see it. The priests, Kapua Tautahi and Werahiko Taipuhi were at the head of the procession as they approached the place: they reciting charms and incantations as they moved along with the people following. All the people carrited green branches in their hands as an offering to Te Awhiorangi. When the concourse drew near the place, successive peals of thunder and flashes of lightning rent the air; then came down a dense fog, making it dark as night. The Tohunga (priests) stopped the thunder and dispersed the darkness by their incantations. When the light again appeared, the people offered the green branches, together with a number of Maori mats, \&c. ; then they made lamentations, and sang the old songs in which the ancient Axe was spoken of by their forefathers."

Thus far the native account. Then follows an enumeration of the articles offered up as propitiation; then a description of the axe, which appears to be a huge and beautiful specimen of the stone weapon, so highly polished that the face of the beholder may be seen reflected in it. Afterwards, the pedigree, or rather the mythological history, of the axe, showing how (name by name) it had been handed down from the first Maori chief who came to New Zealand (Turi), and that it had descended to him, through the great god Tane, from the primæval pair, Heaven and Earth (Rangi and Papa). But our chief interest in it is the thunder heralding its finding.

Wellington, N.Z., June I $\mathrm{r}$.

EDWARD TREgear.

\section{The Dispersion of Seeds and Plants.}

I HAVE read with much interest Mr. Morris's communication on the above subject (NATURE, vol. xxxvii. p. 466), and can corroborate most of what he states from personal observation. I can also remove his doubt respecting the germination of the seeds of the Guava and Pussiflora, to which may also be added the Tomato.

I have adopted the " earth system" in my w.c., and from the place where the earth is deposited may always be gathered fine young plants of the three genera named above.

Thousands of acres of pasturage have been destroyed in this island by the distribution by birds of the Lantana, which was unfortunately introduced here by the first Roman Catholic missionaries, to form a hedge for their property at St. Loulis or Conception. The "Gendarme plant" (an Asclepiad) was brought here in a pillow by a gendarme from Tahiti. It was a seed attached to a wing of silk cotton. The gendarme shook out his pillow; the wind carried the seed to a suitable spot, and now it vies with the Lantana in destroying our pastures.

I have shot the Great Fruit Pigeons of Fiji and this island with several seeds of the Canarium (?) in their crops, as $\mathrm{Mr}$. Morris says, as big as hen's eggs. The seeds of water-plants are conveyed, with the eggs of fresh-water Mollusca, to vast distances, adhering to the hairs and feathers of the legs of water birds--ducks, herons, and waders of all sorts. In London the basins of the fountains in Trafalgar Square were peopled by Lymnea brought thither from the Serpentine, attached to the feathers of the sparrows who bathed, first in one, and then in the other.

Another plant which occurs to me as being largely indebted to man for its distribution, is that known as the "Cape Gooseberry," which is a native of South America (I forget its botanical name). The Kaffirs call it the "White man's plant," and say it follows the white man everywhere. I know it is found in India, Ceylon, Africa, Fiji, New Caledonia, New Hebrides. I really believe boiling it into jam does not destroy the vitality of the seeds. We have just got a plant here, bearing a lovely flower, but whence it comes no one knows. It has hard wooden seed capsules, each furnished with two hooks as hard as steel and as sharp as needles, this size and shape. These, hooking

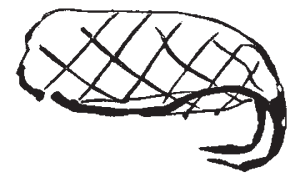

into the hide of any animal, wonld be carried for days until forcibly dislodged.

The "Bathurst burr" (Xanthizm spinosum) was introduced into the Cape in a cargo of wool wrecked at Cape Lagulhas, and spread out to dry, first there, and then at Simon's Town, at both of which places the "burr" sprang up. I believe and hope I destroyed the first and last plant of it that sprang up in New Zealand some twenty-five years ago. The seed had been 